\title{
МІГРАЦІЙНІ ПРОЦЕСИ У ПЕРІОД ПАНДЕМІЇ: ВИКЛИКИ МІЖНАРОДНО-ПРАВОВОМУ РЕГУЛЮВАННЮ
}

\begin{abstract}
Анотація. Статтю присвячено висвітленню актуальної проблеми міжнародно-правового регулювання міграційних процесів в період пандемії COVID-19. Наводиться статистична інформація щодо допандемічного та пандемічного стану мобільності населення. Робиться акцент на спільній міграційній політиці держав з метою подолання наслідків економічного, правового та цивілізаційного характеру, спричинених пандемією. Здійснено спробу спрогнозувати подальші наслідки пандемії COVID-19 для сфер суспільного життя та виявити можливі інструменти правового характеру для корегування міграційних політик держав. Зазначаеться, що, незважаючи на пандемічні обставини, рушійні сили міграційних процесів залишаються класичними і одночасно такими ж впливовими, як і до пандемії - кондлікт, бідність, що посилюеться під впливом пандемії.
\end{abstract}

Ключові слова: міжнародна міграція, міграційна політика, пандемія, фактори міграції, правове регулювання міграції, обмеження пересування.

Chaykovskyy Yuriy

National University "Odessa Law Academy"

\section{MIGRATION PROCESSES DURING THE PANDEMIC PERIOD: CHALLENGES OF INTERNATIONAL LEGAL REGULATION}

Summary. The article is devoted to the current problem of international legal regulation of migration processes during the pandemic COVID-19. Statistical information on the pre-pandemic and pandemic state of population mobility is provided. Emphasis is placed on the common migration policy of states in order to overcome the economic, legal and civilizational consequences caused by the pandemic. An attempt has been made to predict the further consequences of the COVID-19 pandemic for the spheres of public life and to identify possible legal instruments for adjusting the migration policies of the states. It is noted that, despite the pandemic circumstances, the driving forces of migration processes remain classic and at the same time as influential as before the pandemic - conflict, poverty, which is exacerbated by the pandemic. The current crisis has also clearly demonstrated that under no circumstances will it be possible to stop the movement of the population, significantly limit its intensity - yes, but it is impossible to localize migration processes. Further development of the pandemic will address the introduction or lifting of mobility restrictions, adjust migration movements, allow economies to recover or push them into further recession. The economies of many developed countries are migrant-dependent, because their own labor force is no longer sufficient to serve in these global conditions. All this will also significantly affect the size and direction of formal and informal migration flows in the future. First of all, it should be assumed that the existing conditions not only for migration, but also for all spheres of public life in the short and even medium term will be maintained. Secondly, due to uneven economic development, we can observe unequal access to vaccines and different in time economic recovery as the driving forces of migration. The gap between inequality in GDP and living standards will be exacerbated by uneven access to vaccines. As a result, higher-income countries will recover faster. Third, the expected trend is increased pressure on migration policy as a result of the pandemic. As the crisis worsens, it may become increasingly difficult for the developing countries to cooperate on migration control and return.

Keywords: international migration, migration policy, pandemic, migration factors, legal regulation of migration, movement restrictions.

$\prod^{\circ}$ остановка проблеми. Міжнародна міграція набула небаченої інтенсивності в умовах глобалізації. Поряд із рухом товарів, капіталів, інформації, переміщення населення є одніею з найтиповіших характеристик сучасного світу $[1$, с. 5]. Слід зазначити, що узгодження міграційної політики держав - складний і неоднозначний процес. Держави завжди відштовхуються від власних національних інтересів i доволі часто вони не співпадають. Та все ж, питання міжнародної міграції життево важливе як для країн походження, так і країн прийняття мігрантів і не може бути вирішено без узгодження власних інтересів на міжнародній арені. 2020 рік став роком нових викликів міжнародному співтовариству, адже пандемічна загроза COVID-19 знову нагадала, що людству потрібно об'єднувати зусилля з метою виживання.
Аналіз останніх досліджень та публікацій. Проблеми міжнародної міграції в період кризових ситуацій знайшли висвітлення у численних працях зарубіжних та вітчизняних вчених. Серед них дослідження Г. Беккера, А. Гайдуцького, В. Зомбарт, Є. Кияна, Е. Лібанової, Г. Лоурі, Р. Макензі, О. Малиновської, Д. Массей, О. Пархомчука, С. Пирожкова, О. Поєдинок, М. Романюка, Ю. Римаренка, З. Смутчак, У. Томаса та інших.

Виділення невирішених раніше частин загальної проблеми. Вчені-міграціологи, як правило, звертають увагу на нетипові умови міграційних процесів і перспективи їх правового регулювання, проте досліджень змін міграційних політик держав під впливом пандемії не так багато.

Метою даної статті $є$ аналіз змін міграційної політики держав під впливом фрактору пандемії 
через аналіз статистичної інформації та пошук ефективних інструментів міграційної політики держав із регулювання міжнародної міграції.

Виклад основного матеріалу. Пандемія COVID-19 спричинила найгіршу світову кризу 3 кінця Другої світової війни. Причому вона наочно продемонструвала, вивела назовні наявні глибокі зриви на соціальному, економічному та політичному рівнях у всіх суспільствах світу. Міграція не стала винятком, адже пандемія перерізала шляхи мобільності, обмежила свободу пересування, суттево знизила кількість робочих місць, а, відповідно, і доходи працівників, зменшила грошові перекази мігрантів у країни походження. Однак, незважаючи на несприятливі умови, це не поклало край міграції. Світ вчиться жити по-новому, враховуючи пандемічні обмеження, в тому числі в питанні пересування населення через кордони держав. Наявна криза також наочно продемонструвала, що в жодних умовах рух населення зупинити не вдасться, суттєво обмежити його інтенсивність - так, але міграційні процеси локалізувати аж ніяк неможливо. Подальший розвиток пандемії вирішить питання про введення або скасування обмежень мобільності, підкорегує міграційні рухи, дозволить економікам відновитись або підштовхне їх до подальшої рецесії. Економіки багатьох розвинутих країн мігрантозалежні, адже власного трудового ресурсу вже недостатньо для обслуговування в цих глобальних умовах. Все це значною мірою також вплине на розмір та напрямок формальних та неформальних міграційних потоків у подальшому.

Які можна передбачити головні тенденції розвитку міграційних процесів у період пандемії? По-перше, слід виходити 3 того, що наявні умови не лише міграції, але й всіх сфер суспільного життя у короткостроковій і навіть середньостроковій перспективі збережуться. Прогнозований розвиток кризи COVID-19 буде лише посилюватися, враховуючи вже відомі мутації і нові різновиди вірусу. По-друге, через нерівномірний економічний розвиток можемо спостерігати нерівномірний доступ до вакцин та різне в часовому вимірі економічне відновлення як рушійні сили міграції. Між регіонами світу очікуеться збільшення розриву нерівності у ВВП та рівні життя. Цей розрив буде посилений нерівномірним доступом до вакцин. На початку 2021 р. 60\% усіх очікуваних доз вакцин вже були придбані країнами 3 високим доходом, залишаючи лише 40\% для країн 3 нижчим та середнім доходом [2, с. 2]. Країни 3 більш високим рівнем доходу відновляться швидше як в економічному, так і в соціальному плані, а наслідки дисбалансу посилять короткочасний міграційний тиск у 2021 році. Потрете, очікуваною тенденцією є посилений тиск на міграційну політику внаслідок пандемії. Економічний підйом після наслідків COVID-19 може ще більше посилити офіційну та нефрормальну міграцію до розвинутих країн, створивши більше можливостей для новоприбулих іммігрантів, ніж для робочої сили, яка постійно перебуває в межах країн. Така тенденція, ймовірно, буде посилена посиленим еміграційним тиском у країнах 3 низьким та середнім доходом та посиленим попитом на імміграцію в країнах з високим рівнем доходу. Пандемія COVID-19 особливо погіршила соціальну, економічну та політичну ситуацію в багатьох країнах, що розвиваються, які $є$ джерелом міграції до Свропи та Північної Америки. На тлі загострення кризи цим країнам може бути все важче співпрацювати з питань міграційного контролю та повернення. Отже, розвинуті країни повинні робити наголос на подальшому розвитку своїх мігращійних партнерських відносин, а також спрямовувати зусилля міжнародного співтовариства на підтримку країн 3 низьким та середнім рівнем доходу.

Останні оцінки говорять про 272 мільйони міжнародних мігрантів у 2020 році, що становить 3,5\% населення світу. Кількість міжнародних мігрантів зростає помірно, але швидше, ніж населення світу. Причому дві третини всіх міжнародних мігрантів - трудові мігранти. Головною причиною відносного збільшення міжнародної міграції є глобальне зростання конфліктів та насильства. У період між 1993 та 2019 роками кількість переміщених у всьому світі зросла більш ніж утричі - 3 21,4 млн до 79,5 млн; кількість внутрішньо переміщених осіб зросла більш ніж у десять разів 3 4,2 млн. до 45,7 млн. осіб. Внутрішні конфрлікти призводять до найбільшої кількості переміщених осіб. У 2019 році 68\% усіх біженців у всьому світі прибули 3 п’яти країн у тривалих і багатогранних конфрліктних ситуаціях: Сирії, Венесуели, Афрганістану, Південного Судану та М'янми.

Міжнародну мігращію не можна пояснити однією причиною, але існуе низка основних рушіїв, які впливають на розмір, напрямок та структуру потоків міжнародної міграції більше, ніж інші. Такими фракторами $є$ війна та конфлікт, глобалізація економік, прогресивний розвиток технологій та засобів комунікації, зміна демографічних показників, підвищення тривалості життя, підвищення рівня освіти, урбанізація та зміна клімату. Ці драйвери вбудовані у «глобальні структури можливостей», які визначають рішення та сприяють або запобігають окремим проектам міграції. Світові структури можливостей включають географічну близькість або відстань; щільність та рівень контролю міграцї; правила в їзду та проживання; існування та спроможність мереж нелегального перетину кордонів; характеристики систем притулку та захисту; можливості працевлаштування на офіційних та тіньових ринках праці; існування сімейних та соціальних мереж та ступінь співпраці між державами на міграційних шляхах.

Будь-який міграційний прогноз на майбутній період повинен враховувати ці довгострокові тенденції та оцінювати їх потенційний розвиток на основі впливу короткострокових подій. Немає сумнівів, що поява пандемії COVID-19 спричинила не лише глобальну кризу історичних масштабів в галузі охорони здоров'я, але також представляе подію, яка найбільше вплинула на міжнародну мігращію і продовжуватиме свій вплив надалі. Сама пандемія та подальші заходи стримування призвели до найглибшої економічної рецесії з часів Другої світової війни, зробили величезний тиск на системи охорони здоров'я, порушили ланцюги продовольства та постачання та вплинули так чи інакше на всі 
встановлені офріційні та тіньові канали міграції та мобільності.

Початок кризи COVID-19 у березні 2020 року та негайне запровадження широких обмежень щодо мобільності та мігращії одразу ж глибоко вплинули на міжнародну міграцію. Майже всі країни світу запровадили обмеження на поїздки та жорсткий прикордонний контроль. У першій половині 2020 року відбулося зменшення міжнародних поїздок на $65 \%$, що вплинуло не лише на мобільність, а й на міграцію. За підрахунками МОП, у першій половині 2020 року обмеження мобільності зазнали понад 160 мільйонів робітників-мігрантів. За даними МOM, до липня майже 3 мільйони мігрантів опинились на кордоні за межами місця свого звичайного проживання і не змогли повернутися через обмеження пересування [3]. Мігранти зазнали підвищеного ризику для здоров'я, оскільки вони регулярно працюють у складних галузях, живучи в тісних житлових умовах. У той же час стало очевидним, що вони непропорційно часто працюють у «системно відповідних» профресіях, які вважалися необхідними для подолання кризи: сільське господарство, промисловість і т.д.

Не менш важливим $е$ економічний вплив пандемії. Як вже зазначалося вище, економічні диспропорції та зарплати між регіонами світу є головними рушіями міжнародної мігращії. Але економічні фрактори корелюють і з конфліктами. Глибока рецесія, спричинена COVID-19, здійснила додатковий тиск на слабкі урядові структури та загострила внутрішні та міжнародні конорліктні ситуації. Ця тенденція триватиме ще деякий час i, ймовірно, призведе до збільшення переміщення населення всередині та за межі державних кордонів.

За даними оцінки Світового банку, усі регіони світу постраждали від рецесії, але особливо серйозно це відбувається в Латинській Америщі та Карибському басейні з мінус $6,9 \%$ та Південній Азії з мінус 6,7\% [4]. Обидва вони є важливими регіонами походження міграції. Очікується, що пандемія штовхне ще від 88 до 115 мільйонів людей у крайню бідність, більшість із них у Південній Азії та Адрищі на південь від Сахари. Очікуеться збільшення світового населення, яке зазнає продовольчої небезпеки, з 800 мільйонів до 1 мільярда людей. До кінця 2021 року кількість бідних у світі, які живуть у нестабільних і конфрліктних ситуаціях, збільшиться на 14 мільйонів у порівнянні з 2019 роком [2, с. 6]. Ситуація з боргами, особливо в країнах з низьким рівнем доходу, ще більше погіршиться, залишивши мало ресурсів для боротьби 3 пандемією та допомоги економічно найбільш вразливим групам населення. I їx кількість буде зростати. У 2020 році світовий дохід від праці зменшився більш ніж на 10 відсотків порівняно з минулим роком. Однак, маючи 15 відсотків, зниження було значно вищим у країнах з низьким та середнім доходом. Загалом, глобальна втрата доходу дорівнюе втраті понад 240 мільйонів робочих місць. За даними МОП, лише в Латинській Америці через COVID-19 зникло понад 80 мільйонів робочих місць.

Обмеження пересування призвели до 70\% падіння світового туризму. Це також має величезний вплив на економіки та суспільства країн
3 низьким та середнім рівнем доходу, які значною мірою залежать від цього сектору. Оцінки на кінець року свідчать про глобальне падіння грошових переказів на 14\%; ускладнюючи для сімей мігрантів покриття шкільних зборів своїх дітей, медичних витрат, витрат на житло чи навіть харчування [2, с. 8].

Немає сумнівів, що перша половина 2021 року створить величезні виклики для всіх країн щодо пом'якшення наслідків пандемї для здоров'я та економіки. Тим часом є підстави для оптимізму, що прискорений прогрес у впровадженні програм вакцинації дозволить світовому співтовариству поступово подолати кризу. Більшість країн світу продовжуватимуть боротися зі значним рівнем нових випадків короновірусу. Тим не менше, очікується, що глобальна економіка збільшиться на 4\% у 2021 році [4]. Це менше зростання, ніж сподівалося спочатку, але достатне для підвищення економічного оптимізму, споживання та інвестищій. Однак шлях до одужання буде довгим і нерівним серед світових регіонів. Деякі 3 менш розвинутих економік можуть мати навіть вищі темпи зростання, ніж розвинуті, але значно чіткіше відставатимуть за прогнозами допандемічного зростання.

В абсолютному вираженні розрив у нерівності у ВВП та доходах на душу населення збільшиться між регіонами світу. Цей розвиток буде посилений нерівномірним доступом до вакцин. На початку 2021 р. 60\% усіх доз вакцин, які будуть доступні в найближчі 1,5 року, вже були придбані країнами з високим рівнем доходу, залишивши лише $40 \%$ країнам з нижчим та середнім рівнем доходу. Хоча країни з високим рівнем доходу зможуть запропонувати вакцинацію всьому своєму населенню в осяжному майбутньому, це не стане можливим у випадку країн 3 нижчим та середнім рівнем доходу.

Як і в попередні роки, ситуація в европейському регіоні буде фрормуватися внаслідок міграційних подій на Близькому та Близькому Сході, в афрриканських регіонах та Латинській Америці. Це не означає, що інші регіони світу заслуговують на меншу увагу, але основні міграційні рухи до Європи будуть пов'язані із ситуацією в цих регіонах також у 2021 році. Конфлікти та економічні дисбаланси будуть і надалі залишатися основними рушіями пов'язаних потоків. Однак на реальну динаміку сильно впливатиме подальший розвиток пандемії COVID-19, економічні наслідки кризи та ступінь, в якому заходи стримування, обмеження мобільності та прикордонний контроль впливають на структури міграційних можливостей.

Висновки і пропозиції. На подальшу міграційну ситуащію у світі впливатимуть два набори фракторів. По-перше, це довгострокові фрактори, пов'язані з конфрліктом, економічними дисбалансами, соціально-економічним розвитком та демографрічними дисбалансами. По-друге, е наслідки пандемії COVID-19, пов'язані з міграцією, які отримають поширення на наступні роки.

Зазначені фрактори продовжуватимуть нарощувати глобальний потенціал міжнародної міграції. При цьому, конфрлікти будуть і надалі відігравати особливу роль і збільшувати частку втечі та переміщення серед міграційних потоків. 
Пандемія COVID-19 вразила населення у всіх частинах світу, але особливо негативно вплинула на мігрантів та вразливі групи населення. На додаток до втрат людських життів, мігранти непропорційно часто зіштовхувалися з небезпекою для здоров'я, їм доводилося боротися з обмеженнями пересування та втрачати можливості для отримання доходу. Грошові перекази мігрантів впали на $14 \%$ у 2020 році; ускладнюючи для сімей мігрантів покриття їх витрат. Світовий дохід від робочої сили зменшився більш ніж на 10 відсотків, дорівнюючи втраті понад 240 мільйонів робочих місць. У більшості країн та регіонів походження міграції пандемія ще більше посилила політичну та економічну нестабільність та перетворила існуючі труднощі на серйозні гуманітарні кризи. Ця тенденція, ймовірно, триватиме і надалі, що також передбачае посилення міграційного тиску. Також тиск посилиться нерівним доступом до коронавірусних вакцин серед світових регіонів та нерівними шляхами до економічного відновлення.

Пандемія не припинить міграцію. Навпаки, це ще більше погіршить глобальний економічний дисбаланс та посилить тиск на людей, що залучаються до міграційних процесів в пошуках гідного життя чи кращого майбутнього. Коли в березні держави-члени СС запровадили обмеження на поїздки, нерегулярні міграції стрімко зменшились. У квітні відповідні статистичні показники були майже на 80\% нижчими, ніж у тому ж місяці минулого року. Але як тільки було знято обмеження на подорожі, цифри знову зросли і досягли рівня до пандемії в липні. На кінець року вони впали лише на $7,8 \%$ порівняно 3 минулим роком. Заяви на отримання притулку, подані в країнах-членах $\mathrm{CC}$, зменшились на $25,6 \%$ порівняно з 2019 роком, але це також було наслідком затримки прийому та припинення авіаруху із Латинської Америки. COVID-19 мав пом'якшувальну дію на нелегальну міграцію та притулок, але цей ефрект був менш вираженим, ніж можна було очікувати. Окремо слід наголосити на необхідності вирішення протиріч, які існують сьогодні між країнами Свропейського Союзу. Так, країни, в яких спостерігаеться найбільший приток нелегальних мігрантів, наполягають на тому, щоб ввести жорсткі санкції проти тих країн, які не стримують незаконний виїзд своїх громадян в европейські країни [5, с. 57]. При цьому вони можуть використати об’ективну ситуацію обмеження переміщення населення, спричинену пандеміею, у власних інтересах жорсткого закриття кордонів і обмеження допуску мігрантів на власну територію.

На закінчення можна припустити, що як довгострокові фактори міграції, так і коротко- та середньострокові наслідки пандемії COVID-19 швидше посилять, ніж зменшать існуючі глобальні дисбаланси та міграційний тиск у найближчі роки.

\section{Список літератури:}

1. Малиновська О.А. Міграційна політика: глобальний контекст та українські реалії : монографрія. Київ : НІСД, 2018. $472 \mathrm{c}$.

2. ICMPD Migration Outlook 2021 Seven things to look out for in 2021 Origins, key events and priorities for Europe. URL: https://www.icmpd.org/fileadmin/2017/ICMPD_Migration_Outlook_2021.pdf?utm_source=Clever Reach+GmbH+\&utm_medium=email\&utm_campaign=25-01-2021+Migration+Outlook+2021+\%28full+publicati on\%29\&utm_content=Mailing_12489485

3. International Organization for Migration (IOM), COVID-19 and Stranded Migrants, Issue Brief, 2 June 2020.

4. World Bank Group, Global Economic Perspectives, January 2021.

5. Пак Н.А. Міграційна політика Європейського Союзу: проблеми і перспективи. Вісник Харківського національного університету ілені В.Н. Каразіна. Серія "Міжнародні відносини. Еконоліка. Крайнознавство. туризм». 2017. Випуск 6. С. 54-57.

\section{References:}

1. Malinovskaya O. (2018) Migration policy: global context and Ukrainian realities. Kyiv. (in Ukrainian)

2. ICMPD Migration Outlook 2021 Seven things to look out for in 2021 Origins, key events and priorities for Europe (2021). Available at: https://www.icmpd.org/fileadmin/2017/ICMPD_Migration_Outlook_2021.pdf?utm_ source $=$ CleverReach $+\mathrm{GmbH}+\& u$ tm_medium $=$ email\&utm_campaign $=25-01-2021+$ Migration + Outlook $+2021+\% 2$ 8full+publication\%29\&utm_content=Mailing_12489485

3. International Organization for Migration (IOM), COVID-19 and Stranded Migrants, Issue Brief, 2 June 2020.

4. World Bank Group, Global Economic Perspectives, January 2021.

5. Pak N.A. (2017) Migration policy of the European Union: problems and prospects. Bulletin of VN Karazin Kharkiv National University. Series "International Relations. Economy. Local lore. Tourism», vol. 6, pp. 54-57. 